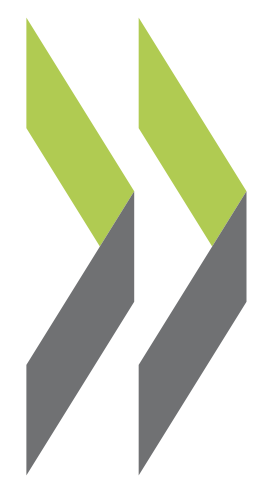

OECD Economics Department Working Papers No. 456

An Overview of Public Policies to Support Innovation

Florence Jaumotte, Nigel Pain 
Organisation de Coopération et de Développement Economiques

ECONOMICS DEPARTMENT

AN OVERVIEW OF PUBLIC POLICIES TO SUPPORT INNOVATION

ECONOMICS DEPARTMENT WORKING PAPERS NO. 456

by

Florence Jaumotte and Nigel Pain

All Economics Department Working Papers are available through OECD's Internet Web site at www.oecd.org/eco 


\section{ABSTRACT/RÉSUMÉ}

\section{AN OVERVIEW OF PUBLIC POLICIES TO SUPPORT INNOVATION}

Innovation is a broad topic, about which much has been written. Almost every kind of public policy has either a direct or an indirect impact on factors that affect innovative activity. The purpose of this paper is to draw out the key implications from selected studies concerning a small number of science-related policies that are widely employed in order to deal with perceived market failures in the innovation process. The main issues considered are fiscal incentives for private $R \& D$, the role of public research organisations, the regulation of intellectual property, the availability of finance, and the supply of skilled human resources for science and technology. Two central themes developed in the paper are the need for accurate evaluation of all these policies, since each may have costs as well as benefits, and the likely enhancement of the wider social benefits from innovation if knowledge is able to diffuse freely, and if potential beneficiaries have sufficient absorptive capacity to be able to understand and use new knowledge productively.

JEL Classification: O30, $\mathrm{O} 38$

Keywords: Innovation, fiscal incentives, intellectual property rights, scientists and engineers, public research organisations

*****************************************

\section{REVUE DES POLITIQUES PUBLIQUES EN FAVEUR DE L'INNOVATION}

L'innovation est un sujet vaste qui a fait l'objet d'une littérature abondante. Presque tout instrument de politique économique a un impact, soit direct, soit indirect, sur les déterminants de l'activité d'innovation. L'objectif de ce papier est de faire le point, à partir d'une sélection d'études, sur un petit nombre de politiques d'innovation couramment utilisées pour remédier aux imperfections de marché dans le processus d'innovation. Celles-ci incluent les incitations publiques aux activités privées de recherche et développement $(\mathrm{R} \& \mathrm{D})$, le rôle des instituts publics de recherche, les droits de propriété intellectuelle, le développement du secteur financier, et la disponibilité de ressources humaines qualifiées en science et technologie. Deux thèmes centraux développés dans le papier sont d'une part le besoin d'une évaluation précise de toutes ces politiques, étant donné que chacune d'entre elles présente à la fois des coûts et des bénéfices, et d'autre part l'importance de la diffusion du savoir qui accroît substantiellement les bénéfices sociaux de l'innovation, à condition que les bénéficiaires potentiels jouissent d'une capacité d'absorption suffisante pour comprendre et appliquer productivement le nouveau savoir.

Classification JEL : O30, $\mathrm{O} 38$

Mots-clef : Innovation, incitations publiques, droits de propriété intellectuelle, scientifiques et ingénieurs, instituts publics de recherche

\section{Copyright OECD 2005}

Applications for permissions to reproduce or translate all, or part of, this document should be made to the Head of Publications Service, OECD, 2 rue André Pascal, 75775 PARIS CEDEX 16, France. 


\section{TABLE OF CONTENTS}

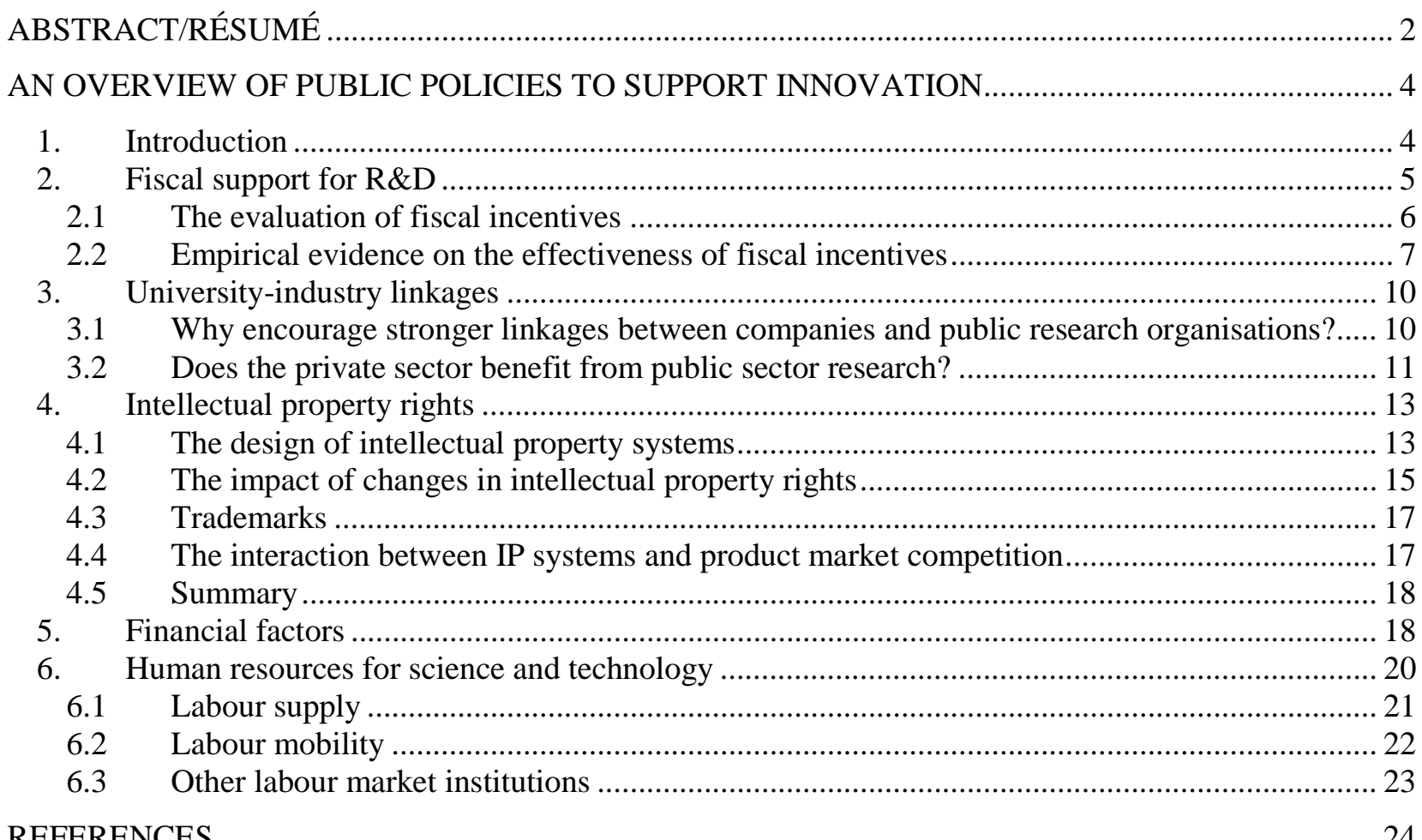




\title{
AN OVERVIEW OF PUBLIC POLICIES TO SUPPORT INNOVATION
}

\author{
by \\ Florence Jaumotte and Nigel Pain ${ }^{1,2}$
}

\section{Introduction}

1. Innovation is a broad topic, about which much has been written. Almost every kind of public policy has either a direct or an indirect impact on factors that affect innovative activity. The purpose of this paper is to draw out the key implications from selected studies concerning a small number of sciencerelated policies that are widely employed in order to deal with perceived market failures. Where possible, use is made of the conclusions from previous surveys of the topics, augmented by an overview of more recent studies. ${ }^{3}$ The paper is one part of a wider research project and is complemented by separate studies of the principal determinants of $\mathrm{R} \& \mathrm{D}$, patenting, the labour market for scientists and engineers and the commercial introduction of innovative products and processes (Jaumotte and Pain, 2005b,c). All of these investigate the influences of specific institutional features of the innovation system and public policies for innovation, building upon the existing approaches in the literature discussed in this paper.

2. The underlying justification for public intervention in the innovation process is that the market will otherwise invest less in innovative activities than would be socially desirable (Nelson, 1959; Arrow, 1962). There are four principal reasons why this might occur -- knowledge spillovers, financial market failures, skilled labour shortages and informational imperfections. The ability of competitors and follow-on innovators to benefit from new knowledge is likely to mean that the social rate of return to knowledge production exceeds the private rate of return (Jones and Williams, 1998). This basic proposition has been used as justification for the development of many different types of policy intervention in the innovation process.

1. The authors are members of the Switzerland/Spain Desk, Country Studies Division I and the Macroeconomic Analysis and Systems Management Division respectively, of the Economics Department of the OECD. The authors are grateful to Mike Feiner, Jorgen Elmeskov, Pete Richardson and other colleagues in the Economics Department and the Science, Technology and Industry Directorate for helpful comments and suggestions, and to Diane Scott for assistance in preparing the document.

2. This study was carried out as part of the ongoing work in the Economics Department on structural adjustment, economic growth and innovation, and was previously presented as part of a wider research report to Working Party 1 of the OECD Economic Policy Committee and to the OECD Committee for Science and Technology Policy. Other parts of that report are also available in the Economics Department Working Paper series, see Jaumotte and Pain (2005a, b and c).

3. More comprehensive surveys of the innovation literature can be found in Cohen (1995) and Fagerberg et al. (2004). The long-term growth of academic interest in innovation and technology is illustrated by Griffiths and Webster (2004). Using a sample of journals published in JSTOR since 1900, they estimate that the proportion with the words innovation and technology in their text has risen from about 5\% in 1900 to over $40 \%$ by 1999 . 
3. This survey focuses on five principal policies designed to ease perceived constraints on the incentive for private firms to innovate:

- Direct public fiscal policies to stimulate innovation, whether through grants or the tax system (Section 2).

- The funding of public research organisations and measures to improve linkages with the private sector (Section 3).

- The regulation of intellectual property (Section 4).

- The availability of finance for innovation expenditures (Section 5).

- The availability of human resources for science and technology (Section 6).

4. Each of these policies are designed to alleviate particular forms of market failure leading to under-investment in innovation. Direct fiscal incentives for private $R \& D$ and programmes offering financial support for small businesses are intended to stimulate additional investment by the private sector. Publicly-owned research organisations can be funded to undertake basic research, or other types of research from which there are few immediate commercial applications. The wider social benefits from innovation are likely to be enhanced if knowledge is able to diffuse freely and if potential beneficiaries have sufficient absorptive capacity to be able to understand and use new knowledge. Educational and labour market policies thus have an important dual role to play in ensuring that there is an adequate supply of skilled human resources available to perform innovative activities and maximise the benefits from the existing stock of knowledge. Awareness about new technologies can also be improved through the use of public funding programmes to promote research collaborations and from information disclosure by innovators who are offered stronger legal protection for their intellectual property rights.

5. Accurate evaluation of each of these policies is essential but difficult, not least because it is often hampered by a lack of knowledge of what would have happened without them, and because many are often used simultaneously. The evidence reviewed below suggests that all can have costs as well as benefits. But if successful, each of the policies can have further secondary influences on the cross-country diffusion of knowledge through their impact on the location decisions of internationally mobile research activities. ${ }^{4}$ The evidence also highlights possible indirect influences from many other public policies on the innovation process (for example, the wider impact of corporate taxation on company cash-flow and capital gains taxation on venture capital provision) and possible policy trade-offs. Such trade-offs are particularly apparent when considering the dual effects of intellectual property policies on incentives to innovate and knowledge dissemination and their interactions with competition policies.

\section{Fiscal support for R\&D}

6. All OECD countries use significant amounts of public money to support activities that are intended to either stimulate private sector innovation or to meet particular socio-economic objectives such as defence and healthcare. Funds are used to support basic and applied research in public research organisations (PROs), as well as to provide direct government support for commercial research and tax incentives for private sector $R \& D$ expenditures. Over time the use of direct grants to institutions and

4. For instance, Kuemmerle (1999) finds that foreign direct investment (FDI) in R\&D laboratories is positively related to the level of R\&D in the target country, and also to the quality of human capital and the existence of centres of scientific excellence. Becker and Hall (2003) find that expenditure on higher education helps to attract high-tech foreign $R \& D$ investments into the United Kingdom. 


\section{ECO/WKP(2005)43}

individual firms has become less important in most economies, with greater emphasis being given to tax measures and the targeting of public funds towards specific projects that are put out to tender.

7. Direct government funding allows public subsidies to be directed towards activities which are thought to offer the highest marginal social returns from research expenditures. In practice, identifying such projects, the appropriate contractors to undertake them and the optimal means by which they should be funded require difficult judgements. Evaluating the outcomes from projects is also difficult, both because of the difficulties in estimating the wider social benefits generated from them, and because of the need to establish what the counter-factual would have been in the absence of public funding.

8. Less is known about the impact of tax credits than of the impact of public grants. In part this is because the use of tax credits is harder to monitor. Tax regimes often offer different incentives according to firm size and location. In many countries tax credits tend to be more generous for smaller firms, whereas direct subsidies are more likely to be received by larger firms (Hall and van Reenen, 2000).

\subsection{The evaluation of fiscal incentives}

9. In general the expected profitability of new research depends on the number uses to which it can be put, either by the organisation undertaking the research, or by others. When new technologies emerge, or new industries develop, the initial market facing potential innovators may be small. This provides one rationale for some types of government support programmes, such as those for small firms, but makes it difficult to assess the eventual benefits from public funds.

10. The difficulties in effective evaluation of individual public programmes to support research are manifold (Klette et al., 2000; Jaffe, 2002). Typically, evaluation proceeds by means of an ex-post assessment of the activities of grant holders. Such evaluations can be subject to selection-bias problems -- grant holders are a non-random group who have been selected often either on the basis of their research history or on the expected quality of the proposed research. ${ }^{5}$ Successful delivery of research results may therefore reflect factors other than the availability of public financial support and the direct additionality of the public funds may be low or even non-existent. ${ }^{6}$ For example, Blanes and Busom (2004) find that previous experience affects the likelihood of individual firms participating in national and regional R\&D programmes in Spain. Small firms and young firms are less likely to participate, possibly implying that some new and potentially innovative firms are not being supported.

11. Even a comparison of funded and non-funded firms may fail to control fully for any selection bias if funding decisions have been made using an accurate ex-ante evaluation of project quality. Such projects would be the most likely to succeed even in the absence of public support. Ex-post evaluation is possible if measures can be found that affect the probability of selection for funding, but not the probability of success. One such study of the Small Business Innovation Research Program in the United States found

5. At the national level, this argument translates into a view that any observed positive correlation between government funding of private $R \& D$ and $R \& D$ intensity may arise because government funding of private research is more likely to occur in those countries in which there are organisations or individuals with a successful track record in undertaking research.

6. The use to which the grantholder puts the financial resources that would otherwise have been used to finance the project is unknown, so there could be additional effects elsewhere in the economy. 
that making this correction resulted in a marked reduction in the apparent positive impact of the programme on innovative activity (Wallsten, 2000). ${ }^{7}$

12. Potential knowledge spillovers also have to be separated out, to the extent this is possible. R\&D programmes may succeed in producing innovations that are used by other firms outside the programmes, raising the social returns from publicly-funded innovative activity. Of course, there need not always be net spillovers from private innovative activities (Klette et al., 2000). Absorptive capacity matters (Cohen and Levintahl, 1989). Firms who do not undertake innovation are less likely to be able to benefit from the knowledge generated by others. For firms with the capacity to learn from others, identifying the relative impact of their own free-standing research is difficult unless they patent or publish, in which case references will be made to the important differences from the work of others.

13. A related question concerns the "additionality" of public funding -- the extent to which public funding leads to a higher level of research expenditure than would otherwise have occurred. ${ }^{8}$ This is different to the question of project success, since a higher level of research (input) expenditure need not lead to greater research output, but many of the underlying issues are similar. Crowding in can occur, if firms face financial constraints that prevent them from otherwise undertaking projects that are expected to yield high returns, but so can crowding out, if diminishing marginal returns to R\&D leads grant holders to reduce their own funding for $R \& D$ expenditure one-for-one with public funds. For some firms, government funding may just be a cheaper source of finance than funding raised from capital markets (Lach, 2002). In such cases public subsidy need not stimulate additional R\&D.

14. Tax incentives are less likely to lead directly to an increase in crowding out, because they reduce directly the marginal cost of R\&D. But it remains possible that they will also have little impact on real resources by raising the prices of inputs that are in fixed supply, at least in the short term. They may also distort the project choices of the private sector, if greater emphasis is given to projects with short-run payback periods in order to make full use of the permitted offset of tax credits against expenses and earnings.

\subsection{Empirical evidence on the effectiveness of fiscal incentives}

15. A series of recent papers have provided detailed overviews of the extant literature on the impact of government subsidies, tax incentives and public research programmes (David et al., 2000; Hall and van Reenen, 2000; Klette et al., 2000). These suggest that there is little consensus as to the effectiveness of subsidies and research programmes, a finding confirmed by the meta-analysis of Garcia-Quevado (2004) using the results from thirty-nine studies of the effectiveness of public subsidies. In contrast, Hall and van Reenen (2000, p. 467) claim that there is "substantial evidence" that tax incentives have a positive effect on the amount of private sector R\&D expenditure. All studies highlight the importance of the control variables included in any empirical assessment, and the level of aggregation in the data set being used. Falk (2004), in a panel study of 21 OECD countries finds that government subsidies have a significant positive effect on business R\&D expenditure only when past R\&D intensity is not controlled for. An interpretation of this is that government subsidies have mainly gone to firms that have previously undertaken $R \& D$.

16. In general, studies using firm level data have been found to be more likely to point towards crowding out than studies at higher levels of aggregation. In part this may be because the latter studies are

7. One possibility would be to undertake evaluation by awarding grants randomly within a pool of applicants all of whom are judged suitable for matching funding (Jaffe, 2002). But this raises the alternative issue of whether social welfare is lower if some worthwhile projects go without funding.

8. The absence of additionality need not reflect the absence of net social benefits if it raises the public availability of the outputs from research, to the benefits of subsequent researchers. 
more likely to capture any indirect spillover benefits from the innovative activities undertaken by the industries and firms receiving public funding. ${ }^{9}$ David et al. (2000) also highlight the possibility that observed aggregate complementarities between publicly-financed and privately-financed R\&D could arise because of the effect of the former on the input prices of the resources used by the latter. If the short-run supply of inputs is inelastic any apparent rise in $R \& D$ intensity in the private sector could just reflect a rise in the relative prices of the real inputs used to undertake R\&D. ${ }^{10}$

17. Guellec and van Pottelsberghe (2000) argue that account should be taken of the overall net effectiveness of all public fiscal instruments, including public financed basic research, since all are employed simultaneously in most OECD economies. Their study points to a positive net overall effect from public funding on the growth of privately financed R\&D, although some forms of funding are found to have positive effects and others to have a negative effect. Government subsidies to the business sector and tax incentives appear to be substitutes. When considered on its own, direct government funding of business $R \& D$ is found to generate significant additional amounts of private funding for $R \& D$, especially if the subsidisation rate is modest. But once tax incentives are allowed for, the effect of government subsidies is greatly reduced. Even allowing for direct net benefits from public support for $R \& D$, there may also be wider economic costs arising from the need to fund public support for innovation. For instance, the analysis in the OECD Growth Study finds that, after controlling for the impact of business R\&D, nonbusiness sector R\&D intensity has a negative impact on economy-wide productivity growth (OECD, 2003a). ${ }^{11}$

18. Government funding may also be motivated by a perceived belief that firms face capital market constraints, especially SMEs (see also Section 5). In an analysis of SMEs in Finland, Hyytinen and Toivanen (2003) report that government funding has a greater impact on the R\&D expenditures of firms in industries that are more dependent on external finance, consistent with what might be expected if there are capital market imperfections. In a related analysis on Israeli data, Lach (2002) finds that government subsidies have a significant positive impact on company financed $R \& D$ expenditure for small firms, but a negative, though insignificant, impact on expenditures by large firms. One interpretation of this finding is that grants to small firms enable projects to be undertaken that would not otherwise be financed. For large firms, the subsidy is more likely to be used to finance activities that would have been undertaken in any event, with any requirement to invest matching funds being met by devoting resources away from other research projects.

19. A detailed overview of the issues involved in the design of $R \& D$ tax incentives and the different systems in place across the OECD is given in Warda (2001) and OECD (2003c). National regimes are compared using the 'B-index', which is based on the before-tax income required to break even on R\&D expenditure of \$1. Guellec and van Pottelsberghe (2000) and Falk (2004) both find that a reduction in this measure has a significant positive effect on the growth of private sector R\&D expenditure. Bloom et al. (2002), in a detailed cross-country examination of the aggregate impact of R\&D tax credits, suggest that tax credits (or changes in real interest rates) can also have significant long-run effects. Their estimates suggest that a sustained $1 \%$ decline in the user cost of R\&D capital would eventually raise privately funded R\&D in the business sector by just under $1 \%$. The first year effect would be much smaller, at just over

9. They also report that crowding out is found more often in studies for the United States than for other countries.

10. Evidence on this issue is discussed below in the section on human resources for science and technology.

11. Negative effects are found also from increases in the tax burden due to high levels of government expenditure. 
$0.1 \%{ }^{12}$ Related results are reported for Italy by Parisi and Sembenelli (2003), whose analysis of a panel of Italian manufacturing firms suggests that the elasticity of $R \& D$ with respect to its price could in fact be even larger (with a $1 \%$ change in the user cost changing R\&D by between $1.5-1.8 \%$ )

20. Such analyses suggest that tax policies can be effective, at least in some circumstances. They do not show that the social gains from such programmes necessarily outweigh the associated compliance and administrative costs, although the wider spillover effects from higher $R \& D$ on to productivity growth (OECD, 2003a) raises the chances that they may do so. ${ }^{13}$ But there is a higher probability of research duplication when support is offered by means of tax reliefs, rather than by grants, and there is less chance of expenditures occurring in areas with high social but relatively low private returns (basic research). New and small firms may also be at a relative disadvantage if support is provided only through the tax system, as such firms may have relatively little taxable income.

21. In some countries tax reliefs are aimed at particular types of research expenditures. One example is the Netherlands, which has had a tax credit for the wage costs of R\&D employees since 1994 (the WBSO). This is intended to provide support for small firms in particular, with graduated rates of credit according to the level of labour expenditure. In a detailed evaluation undertaken using a sample of firms who applied for the WBSO in some years but not others, Poot et al. (2003) find that each €1 of WBSO allowance leads on average to extra R\&D labour expenditure of $€ 1.01-1.02$ in the short term. ${ }^{14}$ Given a negative relationship between the demand for labour and the price of labour (see Jaumotte and Pain, 2005 b), this implies that real R\&D resources have risen. Firms with WBSO funding are also found to have a significantly higher share of sales from new products in total sales (using data from the European Community Innovation Surveys).

22. Even if $R \& D$ tax reliefs are effective, the question remains as to whether the foregone tax revenues could have been better spent on other activities which had a higher social return. In a cost-benefit analysis of different tax incentives with an equivalent ex-ante revenue cost, Russo (2004), using a CGE model with endogenous innovation and labour supply, finds that the welfare gains from R\&D tax credits are considerably higher than those from reductions in corporate or personal incomes taxes. Such results are likely to reflect the parameterisation of the particular model employed, but do illustrate the importance of taking into account the significant welfare benefits generated potentially by spillovers from innovation.

23. A further issue about which little is known is whether $R \& D$ tax reliefs have additional effects through their effect on the international location decisions of research intensive multinational firms. If tax reliefs do affect location decisions, then there may be a growing disadvantage for countries that do not offer them (Poot et al., 2003). The extent to which the benefits from cross-border knowledge spillovers require local research capabilities also matters. If so, there may be a stronger argument for tax reliefs in smaller than in large countries.

12. In an extension of their basic model they also find evidence of significant complementarities between government-funded business R\&D and privately-funded business $R \& D$, consistent with the evidence in Guellec and van Pottelsberghe (2000).

13. Neither does it imply that all countries should seek to increase the generosity of their tax regimes. The OECD country with the most generous tax regime for R\&D undertaken by a representative firm is Spain. Yet Spain is one of the OECD counties with the lowest private sector R\&D intensity. This suggests that attention might also usefully be given to the issue of policy design and the factors that affect the incentive to apply for tax reliefs.

14. Permanent applicants for the WBSO cannot be used, as it is not possible to estimate what their expenditure would be without the tax credit. 


\section{University-industry linkages}

24. The basic research undertaken in universities and other publicly funded research organisations (PROs) is an important source of long-term technological advance and an important input into the private sector research process (see, for instance, Falk, 2004). Yet innovation surveys reveal that universities and public research labs are a key information source for only a relatively small number of firms (Veugelers and Cassiman, 2003). This may simply be because there are relatively few basic innovations for which there is an immediate commercial application. But it could also reflect obstacles preventing firms from either being aware of the work undertaken in PROs or from accessing it, as well as a lack of capacity in the private sector to absorb the full potential benefits of fundamental research.

25. The first part of this section considers some of the motivations for, and effects of, closer linkages between public research institutes and universities and the private sector. In the second part, empirical studies are reviewed, with a focus on two main areas -- the benefits of enhanced inter-sectoral research collaboration and the effects of encouraging a more active management of intellectual property (IP) in the university sector. A third important linkage, arising from the supply and demand for scientists and engineers is discussed below.

\subsection{Why encourage stronger linkages between companies and public research organisations?}

26. Many countries have undertaken policy initiatives in an attempt to stimulate research partnerships between industry and publicly funded research organisations (PROs). Such partnerships might be expected to increase the rate of utilisation and transfer of academic knowledge to the private sector. Three recent examples are targeted legislation designed to increase the extent of research joint ventures, ${ }^{15}$ the development of institutions such as science parks to facilitate technology transfer, and measures to encourage the commercialisation of university intellectual property. The ultimate objectives of such policies are to generate greater economic benefits from publicly funded R\&D.

27. Much attention has been given to the Bayh-Dole Act in the United States in 1980, which allowed universities to retain the intellectual property rights (IPRs) on research results obtained using public funds. ${ }^{16}$ The sharp rise in the number of patents granted subsequently to United States academic institutions has helped to encourage the enactment of related legislation in many other countries. ${ }^{17} \mathrm{~A}$ particular emphasis has often been to provide universities with more control over the IP generated by individual researchers. Detailed overviews of recent trends in patenting by PROs are provided in OECD (2003b) and Geuna and Nesta (2003).

28. At present, rather more is known about the motivations for closer collaboration between universities and private companies than about the economic effects (Poyago-Theotaky et al., 2002; Hall et al., 2003). Industries have an interest in gaining first, and sometimes exclusive, access to new basic research, and also in sponsoring, and sometimes recruiting, key scientific personnel. ${ }^{18}$ For universities, the main incentive is financial, with applied commercial research being a way to attract business research funding and, if successful, licensing income.

15. Examples of such programme include the European Union Framework Programme, the United States Advanced Technology Program and the Japanese ERATO Program

16. Universities had previously been allowed to keep the IP rights only on privately funded research.

17. The empirical evidence about the effectiveness of the Bayh-Doyle Act is discussed in more detail below.

18. In some countries expenditure on basic research also qualifies for additional tax credits. 


\section{2}

Does the private sector benefit from public sector research?

29. The wider economic effects of closer university-industry linkages are difficult to judge. This is especially so in Europe and Japan, where little time series data are available on patenting and licensing by academic institutions. There are potential costs as well as benefits from initiatives to encourage the commercialisation of research undertaken in PROs. For some firms, the ones with direct linkages with public research institutions, it is more likely that collaboration will be beneficial. Collaboration should help them to acquire knowledge that will ultimately generate higher profits and may also help to upgrade the skills of their own scientific workforce. For firms without direct linkages, the gains are less clear. In both cases immediate spillovers are possible only if firms have the capacity to assimilate and build on the scientific and technological knowledge generated by PROs. The results of Berman (1990) suggest that an increase in industry funding of university $R \& D$ expenditures does have a significant positive impact on the volume of industrial (applied) $R \& D$ expenditures, but that the benefits emerge after a considerable lag. ${ }^{19}$ The direct benefits from industry funding may in any case be small; industry funding is only a small fraction of the total funding for non-business R\&D in all OECD economies.

30. The benefits of university research for the private sector may vary by sector and by firm and project size. Using survey data for the United States, Cohen et al. (2002) find that after controlling for industry effects the influence of public research on industrial R\&D is greatest for large firms and start-ups. Survey evidence for Japan also shows that larger firms have a greater propensity to collaborate with universities (Motohashi, 2005). Link and Scott (2005) find that universities are more likely to be invited to participate in research joint ventures when the size of the joint venture increases. Using Community Innovation Survey data for a number of EU economies, Mohnen and Hoareau (2002) and Laursen and Salter (2004) find that firms with a high research intensity are more likely either to source, or to access, university knowledge, consistent with the view that undertaking research enhances the ability to benefit from knowledge generated elsewhere. It is also likely that substantial benefits from closer linkages with universities appear only in a small number of industrial sectors -- principally ICT-related machinery and pharmaceuticals (Laursen and Salter, 2004). Veugelers and Cassiman (2003), using data for Belgium, find that foreign-owned firms are less likely to co-operate with universities. One explanation for this is that their subsidiaries undertake only applied research, with the parent companies undertaking relatively more basic research.

31. Geographical proximity to centres of research may also matter (Jaffe, 1989), possibly because of the enhanced opportunities for the transfer of tacit as well as codified knowledge. One particular means of transferring knowledge from universities to private companies is through contacts and collaborations in science parks located close to universities. Siegel et al. (2003) find that small businesses located in United Kingdom science parks had a higher research productivity, measured in terms of the number of new products and services or patents generated per unit of $R \& D$ expenditure, than equivalent companies located elsewhere.

32. In an analysis of one particular public programme in the United States aimed at fostering university-industry collaboration on high risk projects with a high social value, Hall et al. (2003) found that the key benefit of university involvement was that projects were less likely to be aborted, despite their greater difficulty. One implication of this is that the scientific expertise available at universities is enabling projects to be undertaken that would otherwise not take place if left solely to the private sector.

33. Collaboration between organisations in different sectors, or even different countries, has become an increasingly important requirement for applications to public funding programmes, both in Europe and

19. There may also be long lags between initial research at universities and other means of dissemination, such as journal publications (Crespi and Geuna, 2005). 


\section{ECO/WKP(2005)43}

elsewhere. Hayashi (2003) demonstrates the increasing role of the university sector in Japan in a detailed analysis of the authorship of papers in the Science Citation Index between 1980-2000. By 2000 over half of the papers published by authors in public research institutes and private companies had a co-author affiliated to a university, compared to just over a quarter in 1980. However not all programmes aimed at fostering collaborative research were found to lead to additional output in the companies being supported through public funds. Laursen and Salter (2004) find that firms are more likely to collaborate with universities if they also make use of other external sources of knowledge.

34. Adams et al. (2003) examine the channels through which publicly-owned laboratories in the United States (14\% of total R\&D in 1995) affect expenditures in the laboratories of industrial firms. Active co-operation agreements between the two, in which the costs of research are shared, were found to have a significantly larger impact than other potential means of spillovers, such as patent licensing and movements of scientists and engineers. ${ }^{20}$ It is common for such agreements to give the commercial rights to any innovations to the firms.

35. The relative importance of formal collaboration with universities and other PROs compared to indirect knowledge spillovers from them is explored by Monjon and Waelbroeck (2003), using data drawn from the CIS for France in 1997. The CIS data allows two types of innovating firm to be distinguished (see Jaumotte and Pain, 2005c), ones that introduce products that are new to the firm and new to the market, and others that only introduce innovations that are new to the firm. ${ }^{21}$ Most benefits are found to come from formal collaboration with universities and other PROs, with indirect knowledge spillovers being of more importance for those firms who only imitate existing products and processes. Highly innovative firms -- the ones introducing innovations new to the market -- were also found to receive significant benefits from co-operation with universities located elsewhere in Europe. This finding provides support for the design of policies to encourage research co-operation across national borders.

36. In contrast to these studies, Guellec and Van Pottelsberghe (2000) find that there is a significant negative relationship between $\mathrm{R} \& \mathrm{D}$ expenditures by public research labs and universities and the level of privately funded and performed R\&D. Higher government funding of business R\&D reduces, but does not eliminate, these negative effects on business, which appear to come primarily from public funding of defence-related R\&D. ${ }^{22}$ In the short-term at least this may reflect a higher level of public demand for scientists and engineers whose supply is fixed. This need not mean that defence-related funding, or other funding for basic research is without longer-term benefits. Spillovers may occur but at too long a lag to be picked up by any econometric analysis. Many important technologies have emerged from publicly funded research efforts; notable recent examples include the Internet and World Wide Web, as well as many other applications of ICTs (Sheehan and Wyckoff, 2003).

37. Traditionally, universities and other non-profit PROs could be seen as producers of knowledge, a public good that could be disseminated via journal publications, conference presentations and consulting (Cohen et al., 2002). Greater use of patents provides a further means by which information is made available publicly, but is likely to raise the lag before it can be disseminated. Moves towards a more active use by universities of IP rights on databases and research tools in particular fields (such as biotechnology) also raises the costs of acquiring information for other researchers. An additional change is the gradual shift from public funding of research institutions to public (and business) funding of commercial projects,

20. In part this reflects the fact that industrial labs in co-operative agreement tend to be from firms that are significantly larger than average. But the result arises even after controlling for such factors.

21. The authors refer to these as highly and weakly innovative firms.

22. Mohnen and Hoareau (2002) find that firms receiving government support are more likely to collaborate with universities and government labs. 
where funding is subject to tender and peer review. A possible consequence is that less emphasis is given to basic research with few immediate commercial or policy spin-offs, although relatively little evidence is yet available on the possible tradeoffs between applied and basic research (Geuna and Nesta, 2003).

38. A related question is whether the increasing use of patents by universities and other PROs has led to a dilution in the quality of the research they patent. This has been subject to considerable debate, especially in the United States. Using data on patent citations to measure the impact of the Bayh-Doyle Act on patent quality, Sampat et al. (2003) obtain results that are sensitive to the period of time used to record citations. Their preferred estimates suggest that university patents have continued to be more highly cited than (a random sample of) other patents, but that citations now occur later, on average, than before. The reasons for this are not known. It could reflect an increasing tendency for universities to patent basic, science-related research with fewer immediate spin-off benefits, or it may simply be that complementary information to the patent, such as publication and conference presentations, is being used less often, raising the time taken for the diffusion of new knowledge.

39. Overall, the weight of the evidence does suggest that co-operation between public research organisations and industries is likely to stimulate private sector $R \& D$, but the benefits need not be felt by all types of firms or appear in all industries. The main benefits appear to come from mechanisms that improve flow of information between the two sectors. Enhanced used of IPRs by public research institutes may not always serve this purpose. It is perhaps worth pointing out that the positive correlation between public patenting and private innovation is usually only assumed, rather than demonstrated.

\section{Intellectual property rights}

40. Moves to encourage a more active management of intellectual property by public research organisations are part of a wider strategy in many countries to strengthen the legal rights of IP holders. In practice, there are numerous ways in which intellectual property can be protected. One option is for intellectual property to be kept secret. Although this option is widely used by companies (Cohen et al., 2000), there may be costs for society as a whole if potential follow-on innovators can not access necessary information. An alternative option is to utilise formal protection for intellectual property rights such as patents, copyrights or trademarks. Each of these provides different rights to IP holders; of the three, patents are the most widely used by innovators (see Jaumotte and Pain, 2005c, Figure 10).

41. The first part of this section discusses some of the important factors that need to be considered for policies that aim to change national systems of intellectual property rights. This is followed by a summary of some of the main empirical evidence about the impact of changes in IPRs. The final two subsections discuss the corresponding growth in trademarks, an alternative form of IP protection, and the impact on incentives to innovate that can arise from the interaction between product market competition and the strength of IP protection.

\subsection{The design of intellectual property systems}

42. In almost all countries the general tendency of IP policy for many years has been to offer ever greater protection for the rights of IP holders. This is especially so for patents. Legislative changes have made patent rights easier to enforce, broadened the scope of patentable innovations ${ }^{23}$ and lengthened the period over which many patents may be granted. These changes have been complemented by moves to encourage greater use of intellectual property rights by universities and other public research organisations. Each of these changes can have different economic effects. For example, strengthening enforcement rights

23. An additional implication of this is that the number of claims that can be included in a patent has risen. 


\section{ECO/WKP(2005)43}

during the lifetime of the patent can affect the chances of follow-on innovations in a different way to lengthening the term of the patent.

43. Enhanced protection of intellectual property rights (IPRs) involves costs as well as benefits. Patents provide incentives to undertake research and disclose information, but at the social costs of a potential reduction in the use of inventions during the lifetime of the patent. Disclosure of information about new research is beneficial, not least because it may prevent unnecessary duplication of research efforts. Inventions that might otherwise be kept secret enter the public domain when placed under the protection of patents, but in such a way that they could impede future commercial research, even if exemptions are available for pure scientific research. Stronger patent protection also raises administrative costs, especially in relatively less developed countries, as it increases the burden placed on examiners in patent offices who have to establish whether patent applications in new subject areas should be accepted. ${ }^{24}$

44. The design of intellectual property systems becomes particularly difficult once allowance is made for the possibility of cumulative innovation (Scotchmer, 1991). Follow-on innovators also respond to changes in IP policies. One basic problem is how to provide optimal incentives to encourage both the innovator of a first generation product and the innovator of a second generation product that makes use of the initial innovation. Such concerns are particularly acute in fields such as biotechnology and IT, where many innovations comprise research tools and software and databases that need to be accessed by other researchers. Excessively strong patent rights for first generation innovators could easily be counterproductive if they acted to limit access for potential entrants, especially new firms or junior researchers, and possibly even prevent the subsequent development of product and process enhancements. The difficulties of predicting the sources of new ideas means that they are best encouraged when the costs of entry into the innovation process are kept to a minimum.

45. Markets for technology, such as patent licensing agreements, can offer a partial solution to some of these problems. Not surprisingly, empirical studies show that licensing is more likely in industries with strong patent protection (Gallini, 2002). But even licensing can create welfare losses unless perfect price discrimination amongst potential users is possible by the licensee (Scotchmer, 2003).

46. Strong property rights are not the only potential reward mechanism for innovators. Historically, patent prizes were often used to reward the first to solve particular mathematical or scientific problems. For this mechanism to be effective, the problem to be solved and the method used to award the prize must be clearly identified. It would not necessarily be suitable for rewarding the many innovations that occur with uncertain future commercial applications. ${ }^{25}$

47. There are some examples, notably open source software, where innovative activity appears to take place without any recourse to formal registration of intellectual property rights (Lerner and Tirole, 2002). Different mechanisms serve to promote innovation in such cases. Programmers contribute code in the expectation that this will subsequently enhance their reputation and 'employability'. Employers encourage participation in part because it can enhance the ability of their programmers to make optimal use of the code, using it to produce customised software to undertake firm-specific tasks that standardised software may not be suitable for (Bessen, 2004). There is no reason why both forms of product should not exist. But this example does demonstrate the difficulties of designing an IP system that is optimally suited to all types of innovative activities.

24. Some of the other potential effects of IP systems, such as their use by start-up companies to obtain external finance, and the impact on knowledge flows from public research organisations are expanded on elsewhere in this document.

25. Abramowicz (2003) provides a detailed overview of the difficulties in designing an effective prize system. 
48. In some complex product industries patenting may also be undertaken for strategic reasons, with portfolios of patents being established for defensive reasons; such portfolios help to encourage the development of "patent pools", or cross-licensing agreements. One example is the semi-conductor industry (Hall and Ziedonis, 2001), where multiple patents are often used in the development of a new product. Without agreement, the risk of being subject to patent infringement suits is high. Whilst such agreements can serve the positive function of facilitating the diffusion of knowledge and technologies, there is also a risk that they can raise the barriers to potential entrants that do not yet have any patents in the particular field. ${ }^{26}$

\subsection{The impact of changes in intellectual property rights}

49. The worldwide level of patents has risen sharply over the past two decades, and especially since the early 1990s. Taken together, over 850000 patent applications were filed in European, the United States and Japan patent offices in 2002, compared to 600000 a decade earlier. It is far from clear that this has much to do with the potential positive effect that enhanced patent rights might be expected to have on the underlying strength of innovative activity (Griliches, 1990; Gallini, 2002). Evidence suggests that the effectiveness of patents varies considerably by industry sector and technological field (Cohen et al., 2000; OECD, 2004a); pharmaceuticals, chemicals and scientific equipment are the sectors in which there is the clearest evidence of a link between patent protection and innovative activity. Firms in other sectors are more likely to prefer secrecy or lead-time over competitors to protect their IP.

\section{The frequency and quality of patenting}

50. Changes in the relative frequency with which different forms of IP protection are used, or changes in the relative cost of patenting, could change the frequency of patenting for any given rate of invention. There is some evidence that patenting has become a comparatively more important means of protecting innovation in recent years, especially for inventions that have become fully commercialised (Sheehan et al., 2004; Hussinger, 2004). Eaton et al. (2004) estimate that over half of the rapid increase in patenting at the European Patent Office in the 1990s can be accounted for by reductions in the cost of patenting during this period. Each of these studies implies that the observed growth in the number of patents may not be an accurate guide to the underlying extent of innovative activities. A related point is made by Bessen and Hunt (2004), who find that recent increases in the patenting of business software by United States manufacturing companies have been associated with a reduction in their R\&D expenditures.

51. Other studies also suggest that the strength of particular kinds of intellectual property rights may affect the type of innovative activity that takes place, but not the level of innovation activities. Using a theoretical model in which innovation leads to imitation, but in which imitators are imperfectly informed about innovations, Anton and Yao (2004) suggest that weak property rights may encourage smaller, less valuable innovations, since disclosure is less likely to lead to imitation. Moser (2003), in an analysis of data on products exhibited in world technology fairs in 1851 and 1876, found little evidence that innovative activities were discouraged in countries without patent laws. In contrast, there was strong evidence that the existence of patent laws was related to the distribution of innovative activities across industries. In countries without patent laws, innovative activities were more likely to occur in industries in which secrecy was an effective protection mechanism.

26. This is one example of the many challenges that the intellectual property system can pose for competition policies. For patent pools to be accepted by competition authorities, they may need to offer information to third parties at reasonable rates, or allow individual contributors to make information available to others if they so wish. Lerner and Tirole (2004) develop a theoretical model which suggests that patent pools can be welfare enhancing providing they contain complementary patents. 
52. Patent statistics are count data. For patent claims to be accepted, patent examiners must be satisfied only that an invention adds to existing knowledge and has potential uses. So there is no guarantee that each individual patent is of equal value. Various indicators have been examined in attempts to measure patent quality. Examples include the number of claims per patent application, subsequent citations to the patent, patent renewal rates, and the number of different countries in which the patent is applied for. Using such indicators to generate a composite index of patent quality, Lanjouw and Schankerman (2004) report sector level evidence that there is a negative relationship between research productivity (patents per unit of $R \& D$ expenditure) and average patent quality.

\section{The cross-country impact of changes in IP rights}

53. One widely used summary indicator of cross-country differences in the strength of intellectual property rights is the developed in Ginarte and Park (1997) and updated in Park and Singh (2002). The index is based on an assessment of five aspects of patent laws: the extent of coverage, membership in international patent agreements, duration of protection, provisions for loss of protection and enforcement mechanisms. Its values range from zero to five, with higher values of the index indicating stronger patent protection. ${ }^{27}$ Data are available at five-year intervals since 1980 , with the missing years constructed by linear interpolation between these points. Kanwar and Evenson (2003) report a significant positive relationship between the IP index and economy-wide R\&D intensity in a sample of 18 OECD economies, implying that stronger IPRs stimulate innovation. ${ }^{28}$ Analysis for the OECD Growth Study (OECD 2003; Bassanini and Ernst, 2002) also found evidence of a significant positive correlation between the degree of protection for IP rights and R\&D intensity. Care should be taken in drawing strong conclusions from these findings, since Ginarte and Park (1997) show that it is also possible to use R\&D intensity to account for the cross-country dispersion in the strength of IP protection over time. This is especially true in a sub-sample of countries with a high level of R\&D activity, implying that the strength of IP rights may be partially endogenous to the level of innovation.

54. Studies that seek to examine the impact of the strengthening of patent systems over longer periods of time, of several decades or more, can undertake tests of the long-term impact of fundamental changes in patent rights, rather than just incremental adjustments to patent length and scope. In an analysis of 177 policy shifts in 60 countries over 150 years, Lerner (2002) reports evidence suggesting that the impact of enhanced patent protection is greater in those countries with weaker initial levels of protection. The majority of the increase in patent claims in the country enhancing patent protection was found to come from foreign residents, suggesting that strengthening patent protection, at least to some threshold level, can help to improve access to foreign ideas.

55. A similar point emerges in a survey by Branstetter (2004) of a number of recent studies of the impact of IPRs on innovative activity. Stronger national IPRs appear to have only a limited impact on domestic innovation, but do encourage the deployment of advanced technology by the affiliates of foreignowned firms. ${ }^{29}$ One reason why national patent regimes may be ineffective, at least in small open economies, is that many successful innovations will ultimately be used in products sold in international markets. For such products, the state of foreign IPR regimes matters almost as much as domestic regimes.

27. The score for each category is based on the weighted sum of the scores for a number of additional subcomponents.

28. The other controls included in their panel regression are gross national savings, to capture the availability of finance, the growth of GDP per capita, literacy rates and a black market premium dummy.

29. Further evidence of this is provided by Smarzynska Javorcik (2004), in an analysis of the impact of intellectual property rights on FDI in transition economies. The analysis suggests that the enforcement of IPRs matters as much as their strength to foreign investors. 
It may also be the case that the comparatively restricted knowledge base within small economies raises the likelihood that innovations within the economy will involve foreign firms, and that domestic researchers will have to collaborate with foreign researchers (Guellec and van Pottelsberghe, 2001).

\subsection{Trademarks}

56. Trademarks offer a further means of protecting intellectual property. They are legally protected names or symbols used by producers to protect their product. ${ }^{30}$ The mark can be registered for 10 years at a time, and can be renewed indefinitely as long as the trademark continues to be used. The principal legal effect of the trademark is to act as a signal of the source of origin of the product. There is no automatic legal guarantee of product quality although, in practice, firms may use trademarks as a way of seeking to develop and protect reputational assets. As with patents, changes in the regulations governing the procedures for trademarking may well affect the likelihood of applications.

57. While there has been comparatively little economic analysis of trademarks, existing evidence does suggest that trademarks provide a signal of the extent of product innovation in national economies. Baroncelli et al. (2004) show that the global distribution of trademarks is skewed towards high-income industrial countries, although it is less uneven than the global distribution of patents. They also show that trademark activity is typically concentrated in R\&D intensive sectors, such as pharmaceuticals and scientific equipment. Jensen and Webster (2004) report that the number of trademark applications is significantly related to patent applications, using company level data for Australia. Related results are reported for the United Kingdom by Greenhalgh et al. (2003). ${ }^{31}$

58. Taken together, these findings suggest that it could be useful to explore further whether a trademark-based indicator could be developed to provide a further guide of trends in cross-country innovative activities, alongside patent-based indicators. Trademarks and patents can be complements, because trademarks are typically applied for at the end of the innovative process, when products are about to be introduced into the marketplace. Thus they reflect commercial assets as well as intellectual assets.

\subsection{The interaction between IP systems and product market competition}

59. Intellectual property regimes raise a number of challenges for competition policy. Patents and other forms of IP protect the right of innovators to exclude third parties from using their ideas. But it is difficult to determine whether commercial agreements such as cross-licensing arrangements represent anticompetitive behaviour or simply the legal exercise of intellectual property rights and a practical means of avoiding the "hold-up" problems that can arise when multiple patents are used to introduce new products (Shapiro, 2001). In forming judgements about such factors, policymakers also need to bear in mind that the extent of product market competition can affect incentives to innovate as well as the extent to which knowledge is diffused.

60. The early theoretical literature on patent "races" suggested that incumbent firms with IP rights might be less likely to innovate than new (potential) entrants (Arrow, 1962). The expected gains for incumbent firms are given by difference between expected profits from continuing with the current technology and those expected from the new innovation. For outsiders, the expected gains are the total stream of future expected profits from the new innovation. An empirical implication of this model is that under free competition the technological leaders in each industry should change as innovations take place.

30. In recent years legislation has extended the product characteristics eligible for trademarks to include shapes, sounds and smells.

31. Jensen and Webster (2004) also report that the share of registered trademarks owned by foreign firms has risen over time in Australia. 
More generally, it might also be supposed that higher levels of product market competition reduce the overall level of innovation by reducing the potential monopoly rents that any innovator might enjoy. Neither of these views appears to receive much direct support from the data (Blundell et al., 1999). ${ }^{32}$

61. Once it is recognised that incumbent firms have an incentive to innovate in order to escape competition, and that innovation is typically a cumulative process, it is possible that product market competition could stimulate innovation (Aghion et al., 2001). As competition increases, and more firms move closer to the existing technological frontier of incumbents, the expected future profits of the incumbent are diminished unless they innovate further. Aghion et al. (2002) show that such models imply that there is a hump-shaped relationship between product market competition and innovation, as originally suggested by Schumpeter. At comparatively weak, but rising, levels of competition, the incentive for incumbent firms to innovate and escape competition dominates, especially if competitors already have access to similar technologies. At higher levels of competition this effect diminishes and a negative impact on innovation becomes more likely, reflecting the reduced prospect of sustained future monopoly rents. These effects may also vary over time, as new innovations change the number of firms who are further away from the technological frontier.

62. Models of this type have (potentially) important empirical implications. It is quite possible that the relationship between innovative activities and measures of market competition may be non-linear. It may also vary according to the strength of intellectual property rights (Encaoua and Hollander, 2002). Strong IPRs can offset the potentially beneficial effects of stronger competition on innovation if they prevent the rapid diffusion of knowledge from firms at the technological frontier to potential rivals. In this instance rivals are faced with the additional burden of having to make investments just to catch up with leading firms. The technological gap can thus reduce the returns from innovative activities for competitors and reduce the incentive for incumbents to innovate further to maintain market share.

\subsection{Summary}

63. The overall picture that emerges from the extant literature is that the relationship between the IP system, patenting and innovative activity is a complex one. There are some benefits from having protection for IP rights, but this does not mean that such rights should be increased without limit, especially once account is taken of the cumulative nature of the research process and the dynamics of product market competition. Stronger patent regimes help to direct innovation towards patentable activities; such activities need not offer the greatest benefits for society as a whole. It is also clear that IP regimes can affect industry structure, as well as the extent to which knowledge is diffused both within and across national borders.

\section{Financial factors}

64. Even if it were possible for innovating firms to appropriate all the rents accruing to their innovation there could still be underinvestment in $R \& D$ if finance has to be raised from external parties. Capital market imperfections are known to affect investment in fixed capital (Hubbard, 1998) and many studies suggest that similar problems can arise for investment in research and development (Hall, 2002).

65. If borrowers and lenders have asymmetric information about the risk of investment projects, and lenders are unable to write complete contracts to cover borrowers' behaviour in every eventuality, then there will be a gap between the private rate of return and the cost of external finance. External investors will require a premium to compensate for the agency costs arising from adverse selection (the risk of financing an inherently uneconomic project) and moral hazard (an inability to monitor perfectly the

32. Becker and Pain (2003) also show that enhanced product market competition, as measured by import penetration, has a significant positive impact on business sector R\&D activity. 
allocation of the funds by the borrower). In these circumstances changes in the structure of the firm can affect the premium for external finance, and changes in profitability and internal cash-flow can significantly affect the speed with which credit constrained companies are able to adjust their levels of expenditure on innovative activities.

66. The possibility that the cost of external finance for R\&D investments is likely to be higher than that for alternative forms of investment has long been recognised. R\&D projects are inherently more risky than others, and the probability of asymmetric information between lenders and borrowers is likely to be high. This means that positive cash flow is likely to be an especially important source of finance for many innovative activities (Himmelberg and Petersen, 1994).

67. The likelihood of financial constraints is especially high for (potential) new entrants into the research process, who have no history of successful research and may have limited means of internal finance. This has led to policy programmes targeting fiscal support directly at small firms, and also to measures designed to encourage the development of venture capital markets. If there are informational asymmetries, public funding can act as a mark of quality for private investors, reducing the marginal cost of external funds (Lerner, 1999).

68. Evidence for the United States suggests that increases in venture capital activity in an industry are associated with significantly higher patenting rates. In part this may just reflect a greater incentive to patent ideas in order to attract financial support (Hall and Ziedonis, 2001), but there is also evidence that the patents of firms backed with venture capital are more likely to be cited subsequently than are other patents (Kortum and Lerner, 2000). ${ }^{33}$ The size of the venture capital industry may also be endogenous to the scale of economy-wide innovation, with some studies suggesting that the supply of venture capital funds is higher in countries with a higher knowledge stock (Romain and van Pottelsberghe, 2004).

69. In some circumstances financial market imperfections can give rise to non-linearities in the availability of external finance for innovative activities. For example, the 'financial accelerator' model (Bernanke et al., 1996) suggests that the extent to which external finance is rationed will change as the net worth of the firm changes. If there is asymmetric information, the net worth of the firm acts as a signal about its financial health and creditworthiness. When net worth is high, borrowers have more to lose by defaulting, and have a higher value of collateral assets. Both serve to reduce agency costs. Thus a cyclical upturn that improves cash-flow or asset prices may in turn help to expand the supply of investment funds, stimulating investment by those firms previously facing financial constraints. The opposite mechanism is more likely to occur in a cyclical downturn. In the presence of bankruptcy risk, debt issuance by R\&D intensive firms provides another way of signalling to external investors that managers have confidence in the future prospects of the firm. This can also help to overcome asymmetric information problems.

70. A series of related studies have been undertaken to assess the sensitivity of R\&D expenditure to cash flow in the United States, Japan, the United Kingdom, and a number of euro area countries (Hall, 2002). The results are mixed, with R\&D appearing to be more sensitive to cash-flow in the United States, the United Kingdom and Ireland than in the other economies. ${ }^{34}$ One explanation for this cross-country variation in the importance of cash-flow is that the signals provided by short-term fluctuations in cash-flow may be more acute in those economies for which equity-based financing is the dominate source of finance.

33. Kortum and Lerner (2000) also estimate that R\&D financed through venture capital accounted for $8 \%$ of United States industrial innovation in the period 1983-92, even though it represented only 3\% of total R\&D funds on average.

34. Bond et al. (1999) find for the United Kingdom that cash-flow variation has a significant effect on the decision to undertake $R \& D$, rather than on the level of expenditure itself. 
71. The potential existence of credit constraints also has implications for the response of investment to tax changes. If the availability of internal finance acts as a constraint on investment, then average corporate tax rates matter as well as marginal ones designed to stimulate R\&D activities. ${ }^{35}$ Reductions in marginal rates financed by a broadening of the wider corporate tax base will not necessarily improve cashflow, and the aggregate impact of policy changes will be dependent upon the wider state of firms' balance sheets. $^{36}$

72. Profits and cash-flow can also fluctuate if companies seek to absorb the impact of exchange rate fluctuations in their margins. There is a substantial amount of empirical evidence that changes in both the level of the real exchange rate and the rate of exchange rate volatility can affect the scale and timing of both fixed capital investment and foreign direct investment (Pain and van Welsum, 2003). ${ }^{37}$ A common finding is that there is a negative relationship between the level of net inward FDI into an economy and the level of the real effective exchange rate of that economy. Some studies have also found that an appreciation of the real exchange rate also acts to depress fixed investment (Darby et al., 1999). This issue has not been widely examined in work on innovation. In principle, an appreciation of the exchange rate could stimulate incentives to innovate in order to help escape the associated increase in competitive pressures. However, evidence for the United Kingdom suggests that, after controlling for changes in market demand and import competition, an appreciation of the real sterling effective rate and/or an increase in exchange rate volatility have a significant negative effect on R\&D intensity in manufacturing industries (Becker and Pain, 2003; Becker and Hall, 2003). ${ }^{38}$

\section{Human resources for science and technology}

73. The availability of sufficient human resources for science and technology (HRST) is undoubtedly an important factor for innovative activities to take place. ${ }^{39}$ The present targets for significant increases in national $\mathrm{R} \& \mathrm{D}$ expenditure in many countries will be possible only if there is sufficient growth in scientific and workforce skills (Sheehan and Wyckoff, 2003). This may take some time to materialise, especially given the expected rapid growth in retirements from the science and engineering workforce in many OECD countries over the next two decades. The supply of newly-trained scientists is relatively inelastic in the short-run, reflecting the time required to acquire the necessary human capital. Although it is possible to alleviate shortages in several OECD countries through the temporary or permanent international migration

35. In most OECD countries R\&D is expensed as it is incurred; this will aid cash-flow directly even if there are no additional tax credits available.

36. This does not mean that the tax system should always be biased in favour of internal finance, since a higher proportion of internal finance may offer managers greater discretion to pursue policies at odds with the wishes of external investors. Much then depends on the efficacy of the market for corporate control.

37. For an individual company the impact of exchange rate changes on cash-flow will in general vary according to the extent of their international exposure and factors such as the share of total revenues derived from exporting, the ratio of imported inputs in production and the extent of foreign competition faced in product markets (Nucci and Pozzolo, 2001).

38. Zeitz and Fayissa (1994), using a panel of United States manufacturing firms, find that firms in industries with high levels of $R \& D$ intensity react to an exchange rate appreciation by raising $R \& D$ expenditure. Other firms do not. Their model conflates two effects from exchange rate changes, the competitive pressure effect and the financial pressure effect.

39. The empirical work in Jaumotte and Pain (2005) confirms that cross-country differences in the share of scientists and engineers in total employment account for a considerable proportion of cross-country differences in business sector R\&D intensity. Furman et al. (2002) also demonstrate the extent to which differences in national innovative activities, as measured by patents per capita, are attributable to differences in the numbers of scientists and engineers employed. 
of academics and specialists (such as ICT workers) or through international sourcing (OECD, 2004c, Chapter 6), there are obvious limits to the extent to which this can be done simultaneously in all economies.

74. Public policies designed to support innovative activities need to consider the constraints that may arise from a relatively inelastic supply of science and technology workers, at least in the short-term. Consideration should also be given to the wider range of educational and labour market policies that can help to alleviate supply constraints and encourage the diffusion of scientific knowledge.

\subsection{Labour supply}

75. Education and training policies are likely to have an important impact on innovation. The wide range of recent policy initiatives to increase the supply of human resources for science and technology policies is discussed in detail in OECD (2004b, Chapter 5). One common focus is to introduce incentives and programmes to encourage a greater number of students to take science and technology graduate and postgraduate degrees. On occasions, institutional reforms may also be required to ensure a sufficient supply of places on science and engineering courses (Romer, 2000). ${ }^{40}$ Training policies are also important, because the skills of the general workforce may effect the extent to which firms are able to utilise new technologies and, in particular, process innovations.

76. Increasing the supply of scientists and engineers available to work in R\&D occupations cannot be done by education policies alone. Science graduates need not choose to work as scientists in the country in which they graduate (NSF, 2004). The relative returns from other occupations in the country, especially in financial services, and from science-related jobs in other countries can also affect effective supply. This implies that well-functioning labour markets and attractive career opportunities may also be important if firms and public research organisations are able to attract and retain researchers (Roberts, 2002).

77. Empirical evidence on the long-run elasticity of supply of researchers does support the hypothesis that the market can help to resolve possible future imbalances in the occupational market for scientists and engineers. Ryoo and Rosen (2004) find that the elasticity of supply and educational enrolment decisions of engineering students in the United States are very sensitive to expected career prospects. One implication of this is that any incentives that are available for students who enter science and engineering courses may need to be offered only for a short time. Marey and Borghans (2000) find that changes in the real wages of $R \& D$ workers in the Netherlands have a significant positive long-run impact on labour supply.

78. If the supply of researchers is relatively inelastic, there are additional channels through which publicly funded innovation expenditures may impact on the business sector (David and Hall, 2000; Romer, 2000). In the short run, an increase in publicly financed $R \& D$ spending, either in the public sector or in the form of grants to the private sector, raises the demand for researchers who are in fixed supply. Hence it is possible that such expenditures may result only in an increase in the wages of scientists, with little or no effect on the level of R\&D employment and the real resources available to undertake R\&D. ${ }^{41}$ The crowding out of private sector resources occurs is likely to be higher in countries where the public R\&D

40. For example, there may be internal pressures within educational institutions to either limit teaching workloads or to maintain the relative size of enrolments into different academic disciplines.

41. If public R\&D increases the efficiency of researchers (through the knowledge it generates), the wage of researchers may increase further due to an increased demand for researchers on the part of the private sector. 
sector is large relative to the private R\&D sector. ${ }^{42}$ Crowding out would be welfare improving only if government agencies were able to identify an allocation of scientists and engineers across firms and projects that was better than the one the market would naturally implement.

79. The adverse labour market impact of government expenditure on the real resources available for innovative activities receives some empirical support from Goolsbee (1998), who finds that in the United States the ratio of federal R\&D expenditure to GDP has a significant positive impact on the growth rate of the wages of scientists, but little effect on the growth of their hours worked. His calculations imply that the effect of government policies on the true quantity of R\&D could be over-estimated by between 30 to $50 \%$. Related results are reported for the Netherlands by Marey and Borghans (2000).

80. In the long run, the effect of public $R \& D$ spending on private $R \& D$ employment is ambiguous (and not necessarily negative) as an increase in the relative wages of scientists and engineers should stimulate the future supply of scientists and engineers. A higher level of basic research in public research organisation may also eventually raise the level of innovation in the private sector if there are knowledge spillovers. However, there may be more efficient ways to encourage scientific careers than by subsidizing the wages of all scientific personnel through public R\&D expenditures.

\subsection{Labour mobility}

81. Relatively little is known about the effects of the labour mobility of skilled researchers on the diffusion of knowledge. In general, it might be expected to help to diffuse codified and tacit knowledge about innovations, especially when researchers closely involved in the development of a new technology with high commercial value move from the public sector into the business sector (Zucker et al., 2002). ${ }^{43}$

82. Enhanced labour mobility within the private sector can also lead to the development of science networks with expertise that can be drawn on to solve particular research problems. In a study of British and French electronic establishments Mason et al. (2004) report that the greater intra-company mobility of researchers in the United Kingdom provided the basis for British-based establishments to widen the range of external knowledge sources available for collaborative research, especially with universities. Such linkages are likely to be of particular importance in high-tech industries, where there are rapid changes in the frontier technology. ${ }^{44}$ Related results are reported for the United States by Kim et al. (2005), who find that the patents of firms who employ inventors with university research experience are more likely to cite university patents.

83. A key issue for many countries is the extent of migration of skilled scientists and engineers, including newly qualified postgraduates, across national borders, and the policies that might be available to influence migration decisions (OECD, 2001). Many developed countries offer selective immigration packages for potential immigrants who are scientists and engineers. Survey evidence suggests that many skilled postgraduate migrants are attracted by centres of excellence in research and better opportunities for

42. This is because the elasticity of the wage (marginal productivity) to the number of private researchers is likely to be smaller (in absolute value) when the public sector is large relative to the private sector (David and Hall, 2000).

43. The collaboration of such researchers (and, in particular of "star" scientists) with private companies may also be an equally effective way of diffusing knowledge.

44. In France, business researchers were found to have well-developed links with state-financed research laboratories. But with limited occupational labour mobility, the range of contacts remained relatively fixed over time. This is more likely to be beneficial in industries in which the dominant technology changes less frequently over time. It also allows more resources to be concentrated on longer-term basic research activities. 
research funding (Hansen, 2004). Migration provides a way in which scientific knowledge can be transferred across national borders. Provided countries experience both emigration and immigration (or return migration) of skilled workers there are likely to be benefits for both home and host economies. But if skilled migrants are unlikely to return, countries with significant net outward migration of skilled postgraduates may have cause for concern (Fuentes et al., 2004).

\subsection{Other labour market institutions}

84. Other labour market institutions, such as trade unions and the degree of wage bargaining coordination, may also affect the innovation process (Bassanini and Ernst, 2002). Unions may, for instance, slow the organizational restructuring that is often necessary to achieve the full benefits of process and product innovations, or reduce the internal cash-flow available to finance R\&D expenditures. However, the empirical evidence for this is mixed. In their survey of existing empirical studies, Menezes-Filho and Van Reenan (2003) report that while there appears to be evidence from the United States that unions impede innovation activities, there is little consistent evidence of this kind in studies using data for European countries (including the United Kingdom).

85. Using a cross-sectional sample of manufacturing industries in eighteen OECD countries, the evidence shown in the OECD Growth Study suggests that there is a significant negative relationship between the strength of employment protection legislation (EPL) and R\&D intensity (OECD, 2003a, Table 3.3). This is especially true in high-tech industries. However the negative impact of EPL is weakest in countries that have a coordinated system of wage bargaining. ${ }^{45}$ One possible explanation of this result is that strong labour protection and centralised bargaining allow firms to make full use of the specific competencies of their labour force. ${ }^{46}$

45. See also Bassanini and Ernst (2002). They find that the main benefits for R\&D intensity from co-ordinated bargaining occur in industries with a cumulative knowledge base and incremental innovation.

46. When bargaining is at the national level, expected post-innovation profits are less likely to be affected by higher wage claims in innovating firms. 


\section{REFERENCES}

Abramowicz, M. (2003), “Perfecting Patent Prizes”, Vanderbilt Law Review, vol.56, pp.115-236.

Adams, J.D., E.P. Chiang and J.L. Jensen (2003), “The Influence of Federal Laboratory R\&D on Industrial Research", Review of Economics and Statistics, vol.85, pp.1003-1020.

Agion, P., C. Harris, P. Howitt and J. Vickers (2001), "Competition, Imitation and Growth with step-bystep Innovation", Review of Economic Studies, vol.68, pp.467-492.

Aghion, P., N. Bloom, R. Blundell, R. Griffith and P. Howitt (2002), "Competition and Innovation: an Inverted U Relationship", NBER Working Paper No. 9269.

Anton, J.J. and D.A. Yao (2004), "Little Patents and Big Secrets: Managing Intellectual Property", RAND Journal of Economics, vol.35, pp.1-22.

Arrow, K.J. (1962), "Economic Welfare and the Allocation of Resources to Invention", in R. Nelson (ed.) The Rate and Direction of Inventive Activity, Princeton University Press.

Bassanini, A. and E. Ernst (2002), "Labour Market Institutions, Product Market Regulation and Innovation: Cross-Country Evidence”, OECD Economics Department Working Paper No.316.

Baroncelli, E., C. Fink and B. Smarzynska Javorcik (2004), "The Global Distribution of Trademarks: Stylised Facts", World Bank Policy Research Working Paper 3270.

Becker, B. and S. Hall (2003), "Foreign Direct Investment in Industrial R\&D and Exchange Rate Uncertainty in the UK", National Institute of Economic and Social Research Discussion Paper No. 217.

Becker, B. and N. Pain (2003), "What Determines Industrial R\&D Expenditure in the UK?", National Institute of Economic and Social Research Discussion Paper No. 211.

Berman, E.M. (1990), “The Economic Impact of Industry-Funded University R\&D”, Research Policy, vol.19, pp. 349-355.

Bernanke, B. S., Gertler, M. and Gilchrist, S. (1996), "The Financial Accelerator and the Flight to Quality", Review of Economics and Statistics, vol.78, pp. 1-15

Bessen, J. (2004), “Open Source Software: Free Provision of Public Goods”, Technological Innovation and Intellectual Property Newsletter, Issue 2004:4.

Bessen, J. and R.H. Hunt (2004), “An Empirical Look at Software Patents", Federal Reserve Bank of Philadelphia Working Paper No. 03-17/R.

Blanes, J.V. and I. Busom (2004), "Who Participates in R\&D Subsidy Programs? The Case of Spanish Manufacturing Firms", Research Policy, vol.33, pp. 1459-1476. 
Bloom, N., R. Griffith and J. Van Reenen (2002), "Do R\&D Tax Credits Work? Evidence from a Panel of Countries 1979-1997”, Journal of Public Economics, vol.85, pp. 1-31.

Blundell, R., R. Griffith, R. and J. Van Reenen (1999), "Market Share, Market Value and Innovation in a Panel of British Manufacturing Firms", Review of Economic Studies, vol.66, pp. 529-554.

Branstetter, L.G. (2004), "Do Stronger Patents Induce More Local Innovation?", Journal of International Economic Law, vol.7, pp. 359-370.

Cohen, W. (1995), "Empirical Studies of Innovative Activity", in Handbook of the Economics of Innovation and Technological Change, P. Stoneman (ed.), Oxford: Blackwell.

Cohen, W.M. and D. Levinthal (1989), "Innovation and Learning: Two Faces of R\&D”, The Economic Journal, vol.99, pp. 569-596.

Cohen, W.M., R.R. Nelson and J.P. Walsh (2000), "Protecting their Intellectual Assets: Appropriability Conditions and why U.S. Manufacturing Firms Patent (or not)", NBER Working Paper No.7552.

Cohen, W.M., R.R. Nelson and J.P. Walsh (2002), "Links and Impacts: the Influence of Public Research on Industrial R\&D”, Management Science, vol.48, pp. 1-23.

Darby, J., A. Hughes-Hallet, J. Ireland, and L. Piscitelli (1999), "The Impact of Exchange Rate Uncertainty on the Level of Investment”, Economic Journal, vol.109, pp. C55-C67.

David, P.A. and B.H. Hall (2000), "Heart of Darkness: Modelling Public-Private Funding Interactions inside the R\&D Black Box", Research Policy, vol.29, pp. 1165-1183.

David, P.A., B.H. Hall and A.A. Toole (2000), "Is Public R\&D a Complement or Substitute for Private R\&D? A Review of the Econometric Evidence", Research Policy, vol.29, pp. 497-529

Eaton, J., S. Kortum and J. Lerner (2004), "International Patenting and the European Patent Office: a Quantitative Assessment", Chapter 1 of OECD (2004a).

Encaoua, D. and A. Hollander (2002), "Competition Policy and Innovation", Oxford Review of Economic Policy, vol.18, no.1, pp. 63-79.

Fagerberg, J., D.C. Mowery and R.R. Nelson (2004) (eds.), The Oxford Handbook of Innovation, Oxford: Oxford University Press.

Falk, M. (2004), "What Drives Business R\&D Intensity Across OECD Countries?", WIFO Working Paper No. $236 / 2004$.

Fuentes, A., E. Wurzel and M. Morgan (2004), "Improving the Capacity to Innovate in Germany", OECD Economics Department Working Paper No. 407.

Furman, J.L., M.E. Porter and S. Stern (2002), "The determinants of national innovative capacities", Research Policy, vol.31, pp.899-933.

Gallini, N.T. (2002), “The Economics of Patents: Lessons from Recent U.S. Patent Reform”, Journal of Economic Perspectives, vol.16, no.2, pp. 131-154. 


\section{ECO/WKP(2005)43}

Garcia-Quevado, G. (2004), "Do Public Subsidies Complement Business R\&D? A Meta-Analysis of the Econometric Evidence", Kyklos, vol.57, pp. 87-102.

Ginarte, J.C. and W.G. Park (1997), "Determinants of Patent Rights: a Cross-National Study", Research Policy, vol.26, pp. 283-301.

Greenhalgh, C., M. Longland and D. Bosworth (2003), "Trends and Distribution of Intellectual Property: UK and European Patents and UK Trade and Service Marks 1986-2000”, Report for Intellectual Property and Innovation Directorate, UK Patent Office.

Griffith, R., S. Redding and J. Van Reenan (2003), "R\&D and Absorptive Capacity: Theory and Empirical Evidence", Scandinavian Journal of Economics, vol.105, pp. 99-118.

Griliches, Z. (1990), "Patent Statistics as Economic Indicators: a Survey", Journal of Economic Literature, vol.28, pp. 1661-1707.

Guellec, D. and B. Van Pottelsberghe (2000), "The Impact of Public R\&D Expenditure on Business R\&D”, STI Working Paper 2000/4, OECD, Paris.

Guellec, D. and B. Van Pottelsberghe (2001), “The Internationalisation of Technology Analysed with Patent Data", Research Policy, vol.30, pp. 1253-1266.

Guena, A. and L. Nesta (2003), "University Patenting and its Effects on Academic Research", SPRU Electronic Working Paper Series No. 99.

Hall, B.H. (2002), "The Financing of Research and Development", Oxford Review of Economic Policy, vol.18, no.1, pp. 35-51.

Hall, B.H., A.N. Link and J.T. Scott, (2003) "Universities as Research Partners", Review of Economics and Statistics, Vol.85, pp. 485-491.

Hall, B.H. and J. Van Reenan (2000), "How Effective are Fiscal Incentives for R\&D? A Review of the Evidence", Research Policy, vol.29, pp. 449-469.

Hall, B.H. and R.H. Ziedonis (2001), "The Patent Paradox Revisited: an Empirical Study of Patenting in the U.S. Semiconductor Industry", RAND Journal of Economics, vol.32, pp. 101-128.

Hansen, W. (2004), "EU-25 Scientists and Engineers International Mobility", presented at Productivity, Innovation and Value Creation Conference, Amsterdam, June 2004.

Hayashi, T. (2003), "Effect of R\&D Programmes on the Formation of University-Industry-Government Networks: Comparative Analysis of Japanese R\&D Programmes", Research Policy, 32, 1421-1442.

Himmelberg, C.P. and B.C. Petersen (1994), "R\&D and Internal Finance: a Panel Study of Small Firms in High-Tech Industries", Review of Economics and Statistics, vol.76, pp. 38-51.

Hubbard, R.G. (1998), "Capital Market Imperfections and Investment”, Journal of Economic Literature, vol.XXXVI, pp. 193-225.

Hussinger, K. (2004), "Is Silence Golden? Patents versus Secrecy at the Firm Level", ZEW Discussion Paper, No. 04-78. 
Hyytinen, A. and O. Toivanen (2003), "Do Financial Constraints hold back Innovation and Growth? Evidence on the Role of Public Policy", ETLA Discussion Paper No.820.

Jaffe, A.B. (1989), "Real Effects of Academic Research", American Economic Review, vol.79, pp. 957970.

Jaffe, A. B. (2002), "Building Programme Evaluation into the Design of Public Research-Support Programmes", Oxford Review of Economic Policy, vol.18, no.1, pp. 22-34.

Jaumotte, F. and N. Pain (2005a), "Innovation Policies and Innovation in the Business Sector", OECD Economics Department Working Paper no.459.

Jaumotte, F. and N. Pain (2005b), "From Ideas to Development: The Determinants of R\&D and Patenting", OECD Economics Department Working Paper no.457.

Jaumotte, F. and N. Pain (2005c), "From Innovation Development to Implementation: Evidence from the Community Innovation Survey", OECD Economics Department Working Paper no.458.

Jensen, P.H. and E. Webster (2004), "Patterns of Trademarking Activity in Australia", Intellectual Property Institute of Australia Working Paper No.03/04.

Jones, C.I. and J.C. Williams (1998), "Measuring the Social Return to R\&D", Quarterly Journal of Economics, vol.113, pp. 1119-1135.

Kanwar, S. and R. Evenson (2003), "Does Intellectual Property Protection Spur Technological Change?", Oxford Economic Papers, vol.55, pp. 235-264.

Kim, J., S.J. Lee, and G. Marschke (2005), "The Influence of University Research on Industrial Innovation", NBER Working Paper No. 11447.

Klette, T.J., J. Møen and Z. Griliches (2000), "Do Subsidies to Commercial R\&D Reduce Market Failures? Micro-Econometric Evaluation Studies", Research Policy, vol.29, pp. 471-495.

Kortum, S. and J. Lerner (2000), “Assessing the Contribution of Venture Capital to Innovation”, RAND Journal of Economics, vol.31, pp. 674-692.

Kuemmerle, W. (1999), "The Drivers of Foreign Direct Investment into Research and Development: an Empirical Investigation", Journal of International Business Studies, vol.30, pp. 1-24.

Lach, S. (2002), "Do R\&D Subsidies Stimulate or Displace Private R\&D? Evidence from Israel”, Journal of Industrial Economics, Vol.L, pp. 369-390.

Laursen, K. and A. Salter (2004), "Searching High and Low: What Types of Firms use Universities as a Source of Innovation?", Research Policy, vol.33, pp. 1201-1215.

Lanjouw, J.O. and M. Schankerman (2004), "Patent Quality and Research Productivity: Measuring Innovation with Multiple Indicators", The Economic Journal, vol.114, pp. 441-465.

Lerner, J. (2002), "150 Years of Patent Protection", American Economic Review Papers and Proceedings, vol.92, pp. 221-225. 


\section{ECO/WKP(2005)43}

Lerner, J. and J. Tirole (2002), "Some Simple Economics of Open Source", Journal of Industrial Economics, vol.50, pp.197-234.

Lerner, J. and J. Tirole (2004), "Efficient Patent Pools", The American Economic Review, vol.94, pp. 691710.

Link, A. and J. Scott (2005), "Universities as Partners in U.S. Research Joint Ventures", Research Policy, vol.34, pp.385-393.

Marey, P. and L. Borghans (2000), "Wage elasticities of the supply of knowledge workers in the Netherlands", Research Centre for Education and the Labour Market Paper No. ROA-R-2000/6E.

Mason, G., J.P. Beltramo and J.J. Paul (2004), "External Knowledge Sourcing in Different National Settings: a Comparison of Electronics Establishments in Britain and France", Research Policy, vol.33, pp. 53-72.

Menezes-Filho, N. and J. Van Reenan (2003), "Unions and Innovation: a Survey of the Theory and Empirical Evidence", CEPR Discussion Paper No.3792.

Mohnen, P. and C. Hoareau (2002), "What Type of Enterprise Forges Close Links with Universities and Government Labs? Evidence from CIS 2", MERIT Research Memorandum 2002-008.

Monjon, S. and P. Waelbroeck (2003), "Assessing Spillovers from Universities to Firms: Evidence from French Firm-Level Data”, International Journal of Industrial Organisation, Vol.21, pp. 1255-1270.

Moser, P. (2003), "How Do Patent Laws Influence Innovation? Evidence from Nineteenth-Century World Fairs", NBER Working Paper 9909.

Motohashi, K. (2005), "University-industry collaborations in Japan: The Role of New Technology-Based Firms in Transforming the National Innovation System", Research Policy, vol.34, pp.583-594.

Nelson, R.R. (1959), "The Simple Economics of Basic Scientific Research", Journal of Political Economy, vol.67, pp. 297-306.

NSF (2004), Science and Engineering Indicators 2004, U.S. National Science Foundation.

Nucci, F. and A.F. Pozzolo (2001), "Investment and the Exchange Rate: an Analysis with Firm Level Panel Data", European Economic Review, vol.45, pp. 259-283.

OECD (2001), International Mobility of the Highly Skilled.

OECD (2003a), The Sources of Economic Growth in OECD Countries.

OECD (2003b), Turning Science into Business: Patenting and Licensing at Public Research Organisations.

OECD (2003c), Tax Incentives for Research and Development: Trends and Issues.

OECD (2004a), Patents, Innovation and Economic Performance: Conference Proceedings.

OECD (2004b), OECD Science Technology and Industry Outlook. 


\section{OECD (2004c), OECD Information Technology Outlook.}

Pain, N. and D. van Welsum (2003), "Untying the Gordian Knot: the Multiple Links between Exchange Rates and Foreign Direct Investment", Journal of Common Market Studies, vol.41, pp. 823-846.

Parisi, M.L. and A. Sembellini (2003), "Is Private R\&D Spending Sensitive to its Price? Empirical Evidence on Panel Data for Italy", Empirica, vol.30, pp. 357-377.

Park, W.G. and S. Wagh (2002), "Index of Patent Rights", in Economic Freedom of the World 2002: Annual Report, The Cato Institute.

Poot, T., P. den Hertog, T. Grosfeld and E. Brouwer (2003), "Evaluation of a Major Dutch Tax Credit Scheme (WBSO) aimed at Promoting R\&D", presented at FTEVAL Conference on the Evaluation of Government Funded R\&D, Vienna, April 2003.

Poyago, J., J. Beath and D.S. Siegel (2002), "Universities and Fundamental Research: Reflections on the Growth of University-Industry Partnerships", Oxford Review of Economic Policy, vol.18, no.1, pp. 10-21.

Roberts, Sir G. (2002), SET for Success: The Supply of People with Science, Technology, Engineering and Mathematics Skills, report for the U.K. Government.

Romain, A. and B. Van Pottelsberghe (2004), "The Determinants of Venture Capital: Further Evidence", Economic Research Centre Discussion Paper No. 19/2004, Deutsche Bundesbank.

Romer, P.M. (2000), "Should the Government Subsidize Supply or Demand in the Market for Scientists and Engineers?", NBER Working Paper 7723.

Russo, B. (2004), “A Cost-Benefit Analysis of R\&D Tax Incentives", Canadian Journal of Economics, vol.37, pp. 313-335.

Sampat, B.N., D.C. Mowery and A.A. Ziedonis (2003), "Changes in University Patent Quality after the Bayh-Doyle Act: a Re-examination", International Journal of Industrial Organisation, Vol.21, pp. 1371-1390.

Scotchmer, S. (1991), "Standing on the shoulders of giants: cumulative research and the patent law", Journal of Economic Perspectives, vol.5 no.1, pp.29-41.

Scotchmer, S. (2003), "Intellectual Property: When is it the Best Incentive Mechanism for S\&T Data?", in The Role of Scientific and Technical Data and Information in the Public Domain: Proceedings of a Symposium, Washington D.C.: National Academies Press.

Shapiro, C. (2002), “Competition Policy and Innovation”, STI Working Paper 2002/11, OECD.

Sheehan, J. and A. Wyckoff (2003), "Targeting R\&D: Economic and Policy Implications of Increasing R\&D Spending”, STI Working Paper 2003/8, OECD.

Sheehan, J., C. Martínez and D. Guellec (2004), "Understanding Business Patenting and Licensing: Results of a Survey", Chapter 4 of OECD (2004a). 


\section{ECO/WKP(2005)43}

Siegel, D., P. Westhead and M. Wright (2003), "Assessing the Impact of University Science Parks on Research Productivity: Exploratory Firm-Level Evidence from the United Kingdom", International Journal of Industrial Organisation, Vol.21, pp. 1357-1369.

Smarzynska Javorcik, B. (2004), "The Composition of Foreign Direct Investment and Protection of Intellectual Property Rights: Evidence from Transition Economies", European Economic Review, vol.48, pp. 39-62.

Wallsten, S. (2000), "The Effect of Government-Industry R\&D Programs on Private R\&D: the Case of the Small Business Innovation Research Program", RAND Journal of Economics, vol.21, pp. 82-100.

Warda, J. (2001), "Measuring the Value of R\&D Tax Treatment in OECD Countries", OECD STI Review, No.27, OECD.

Zeitz, J. and B. Fayissa (1994), "The Impact of Exchange Rate Changes on Investment in Research and Development", The Quarterly Review of Economics and Finance, vol.34, pp. 195-211.

Zucker, L.G., M.R. Darby and M. Torero (2002), "Labor Mobility from Academe to Commerce", Journal of Labor Economics, vol.20, pp. 629-660. 


\section{WORKING PAPERS}

The full series of Economics Department Working Papers can be consulted at www.oecd.org/eco/Working_Papers/

455. Strengthening Regulation in Chile: The Case of Network Industries (November 2005) Alexander Galetovic and Luiz de Mello

454. Fostering Innovation in Chile (November 2005) José-Miguel Benavente, Luiz de Mello and Nanno Mulder

453. Getting the most out of public sector decentralisation in Mexico (October 2005) Isabelle Joumard

452. Raising Greece's Potential Output Growth (October 2005) Vassiliki Koutsogeorgopoulou and Helmut Ziegelschmidt

451. Product Market Competition and Economic Performance in Australia (October 2005) Helmut Ziegelschmidt, Vassiliki Koutsogeorgopoulou, Simen Bjornerud and Michael Wise

450. House Prices and Inflation in the Euro Area (October 2005) Boris Cournède

449. The EU's Single Market: At Your Service? (October 2005) Line Vogt

448. Slovakia's introduction of a flat tax as part of wider economic reforms (October 2005) Anne-Marie Brook and Willi Leibfritz

447. The Education Challenge in Mexico: Delivering Good Quality Education to All (October 2005) Stéphanie Guichard

446. In Search of Efficiency: Improving Health Care in Hungary (October 2005) Alessandro Goglio

445. Hungarian Innovation Policy: What's the Best Way Forward? (October 2005) Philip Hemmings

444. The Challenges of EMU Accession Faced by Catch-Up Countries: A Slovak Republic Case Study (September 2005) Anne-Marie Brook

443. Getting better value for money from Sweden's healthcare system (September 2005) David Rae

442. How to reduce sickness absences in Sweden: lessons from international experience (September 2005) David Rae

441. The Labour Market Impact of Rapid Ageing of Government Employees: Some Illustrative Scenarios (September 2005) Jens Høj and Sylvie Toly

440. The New OECD International Trade Model (August 2005) Nigel Pain, Annabelle Mourougane, Franck Sédillot and Laurence Le Fouler

439. The French Tax system: Main characteristics, recent developments and some considerations for reform (July 2005) Willi Leibfritz and Paul O'Brien 


\section{ECO/WKP(2005)43}

438. The Effects of EMU on Structural Reforms in Labour and Product Markets (July 2005) Romain Duval and Jørgen Elmeskov

437. Product Market Competition andEconomic Performance in New Zealand (July 2005) Annabelle Mourougane and Michael Wise

436. Getting the Most out of Public Sector Decentralisation in Spain (July 2005) Isabelle Joumard and Claude Giorno

435. Sources of Inflation Persistence in the Euro Area (July 2005) Boris Cournède, Alexandra Janovskaia, Paul van den Noord

434. Measuring Cyclically-Adjusted Budget Balances for OECD Countries (July 2005) Nathalie Girouard and Christophe André

433. Product Market Competition and Economic Performance in the United Kingdom (June 2005) Maria Maher and Michael Wise

432. The Benefits of Liberalising Product Markets and Reducing Barriers to International Trade and Investment: the Case of the United States and the European Union (June 2005)

431. Boosting Growth through Greater Competition in Denmark (May 2005) Martin Jørgensen

430. Fifteen Years of Economic Reform in Russia: What Has Been Achieved: What Remains to be Done? (May 2005) Rudiger Ahrend and William Tompson

429. Assessing the OECD Job Strategy: Past Developments and Reforms (May 2005) Nicola Brandt, Jean-Marc Burniaux and Romain Duval

428. Ageing, Welfare Services and Municipalities in Finland (May 2005) Jens Lundsgaard

427. The Impact of Structural Policies on Trade-Related Adjustment and the Shift to Services (April 2005) Per Mathis Kongsrud and Isabelle Wanner

426. Product Market Competition and Economic Performance in Iceland (April 2005) Thomas Laubach and Michael Wise

425. Enhancing Brazil's Regulatory Framework for Network Industries: The Case of Electricity, Oil and Gas, and Water and Sanitation (April 2005) Edmar Almeida and Nanno Mulder

424. Education Attainment in Brazil: The Experience of FUNDEF (April 2005) Luiz de Mello and Mombert Hoppe

423. Estimating a Fiscal Reaction Function: The Case of Debt Sustainability in Brazil (April 2005) Luiz de Mello

422. Product Market Competition and Economic Performance in the Netherlands (April 2005) Maria Maher and Michael Wise

421. Product Market Competition and Economic Performance in Canada (April 2005) Maria Maher and Jay Shaffer 